\title{
DISTRIBUTION AND HABITAT PREFERENCE OF HISPID HARE (CAPROLAGUS HISPIDUS) IN SHUKLAPHANTA NATIONAL PARK, NEPAL
}

\author{
Dhirendra Bahadur Chand" \\ Laxman Khanal \\ Mukesh Kumar Chalise
}

\begin{abstract}
Hispid hare (Caprolagu shispidus) is an endangered lagomorph which had a wide range of distribution in the past, but currently it is known to occur only from few isolated tall grass pockets of India and Nepal. We explored the population status, habitat utilization and existing threats of the Hispid hare at Shuklaphanta National Park (SNP) by the strip transect and quadrate sampling methods from November 2015 to May 2016 covering both winter and summer seasons. Four study sites of total 1.58ha were selected within SNPand strip transects were randomly laid to determine presence and absence of pellets of Hispid hare and their counts were used to estimate the population density. The Population density of Hispid hare was found to be $0.1820 /$ ha in winter and $0.2268 /$ ha in summer with the statistically significant preference to the tall grassland habitat. Twelve grass species were identified in the habitat of Hispid hare with dominancy of Saccharum spontaneum, Imperata cylindrica, Narenga porphyrocoma, and Saccharum munj. Among the grasses, Imperata cylindrica and Narenga porphyrocoma were the food species of higher preference for Hispid hare.
\end{abstract}

Key words: Hispid hare (Caprolagus hispidus), Shuklaphanta National Park, pellet density, distribution, habitat preference

\section{INTRODUCTION}

Hispid hare (Caprolagus hispidus) is locally known as Pudkekharayo or thulo muso in Nepal (Chalise, 2014). It is listed as an Endangered species in IUCN Red list (2016) and on Appendix-I of CITES, and protected by the DNPWC Act-1973 of Nepal (Tandon, 2009). Historically the species was distributed throughout the southern Himalayan foothills from Uttar Pradesh

* Mr. Chand is associated with Mid Western University, Surkhet; Mr. Khanal is associated with Kunning Institute of Zoology, University of CAS, China and Dr. Chalise is Professor of Zoology, Central Department of Zoology and corresponding author, Kirtipur, TU. 
of India through Nepal and West Bengal to Assam of India, extending southwards as far as Dhaka in Bangladesh. Present day, Hispid hare is known to exist only in a few isolated pockets across range of tall grassland habitats in India and Nepal, however, the present distribution range in Nepal is not well-known because of insufficient evidences of its distribution from limited researches.

Weighing about $2.5 \mathrm{~kg}$ it is also called "bristly rabbit" because of its coarse, dark brown hair. It prefers tall grass-scrub savanna, in flat, welldrained and thinly forested areas. It is not gregarious but sometimes lives in pairs and the breeding season starts from January (Bell, 1987, Shrestha 1997). It mostly prefers to stay in certain area and eat the grass species present in that area instead of bringing food from different areas. Its diet consists mainly of bark, shoots and roots and inner core of grasses like Narengaporphyrocoma, Imperata cylindrica, Saccharum spontaneum and leaves of Cymbopogan sp., (Oliver, 1980,Yadav, 2005) including thatch species, and occasionally the crops. It is dependent on the early successional riverine vegetation communities, typically comprising dense tall grasses, commonly referred to as elephant grass or thatch grass, that grow to a height of over $3 \mathrm{~m}$ (Maheswaran, 2002). Indian fox, jackal, jungle cat, leopard, large and small Indian civets, tiger and crested serpent eagle are the major predators of the species (Bell, 1987). With increasing human pressure on grassland, a very limited area is left as a refuge for small mammals. To add on this, the ecological consequences on many of small mammals like Hispidhare in Indian subcontinent are unknown and inventories of these species in the grassland are poor as compared to large mammals, pushing them to the brink of extinction (Adhikari, 2001, Oliver 1979, 1980 \& 1985). Habitat destruction due to overgrazing, uncontrolled thatch grass cutting practices, unscientific burning (Maheswaran, 2002), succession of grasslands into woodlands, weed invasion and rampant hunting are threatening the existence of this poorly known species (Nath, Sarkar, Machry, 2010). Chapman \& Flux (1990) had suggested for the captive breeding program for hispid hare while Bell (1986) emphasized that the captive breeding program of the species didn't succeed and therefore it is rarely kept in captivity (Wilson, 1924). This even raises a serious question for its long-term survival outside the natural habitat. The arguments due to lack of study, still are arising in the existence of this elusive species outside the Shuklaphanta National Park in Nepal, though it is reported to be occurring also in Chitwan National Park (CNP) and Bardia National Park (BNP) of 
Nepal (Inskipp \& Collar, 1984, Oliver, 1985 \& Yadav, 2005). Bell (1986) studied about the behavioral ecology, home range and potential threats on Hispid hare and Aryal, Brunton, Ji, Yadav, Adhikary \& Raubeheimer (2012) explored the diet and habitat use in the then Shuklaphanta Wildlife Reserve (present SNP). But due to the research gaps, very little is known about the present status and conservation threats of Hispid hare in the SNP. Biological data, which includes the current population status, habitat utilization, the survival threats and conservation strategies for the endangered species of Hispid hare in Nepali dentifies the key process for conservation by effective management approaches.

\section{MATERIALS AND METHODS}

\section{Study area (SNP)}

The SNP (Fig. 1) is situated in the southwestern Tarai in the Kanchanpur district of Far-Western Nepal (Latitude 28 45'16" \& longitude $80^{\circ} 06^{\prime} 04^{\prime \prime}$ E) (Adhikari 2003). It is bordered on three sides by the Mahakali River which marks its Western and southern boundaries that also represent the international border with India. It was established as a Wildlife Reserve in 1975 and declared as a National Park in 2016.

Fig.1: Study area, Shuklaphanta National Park (SNP) DNPWC 2013

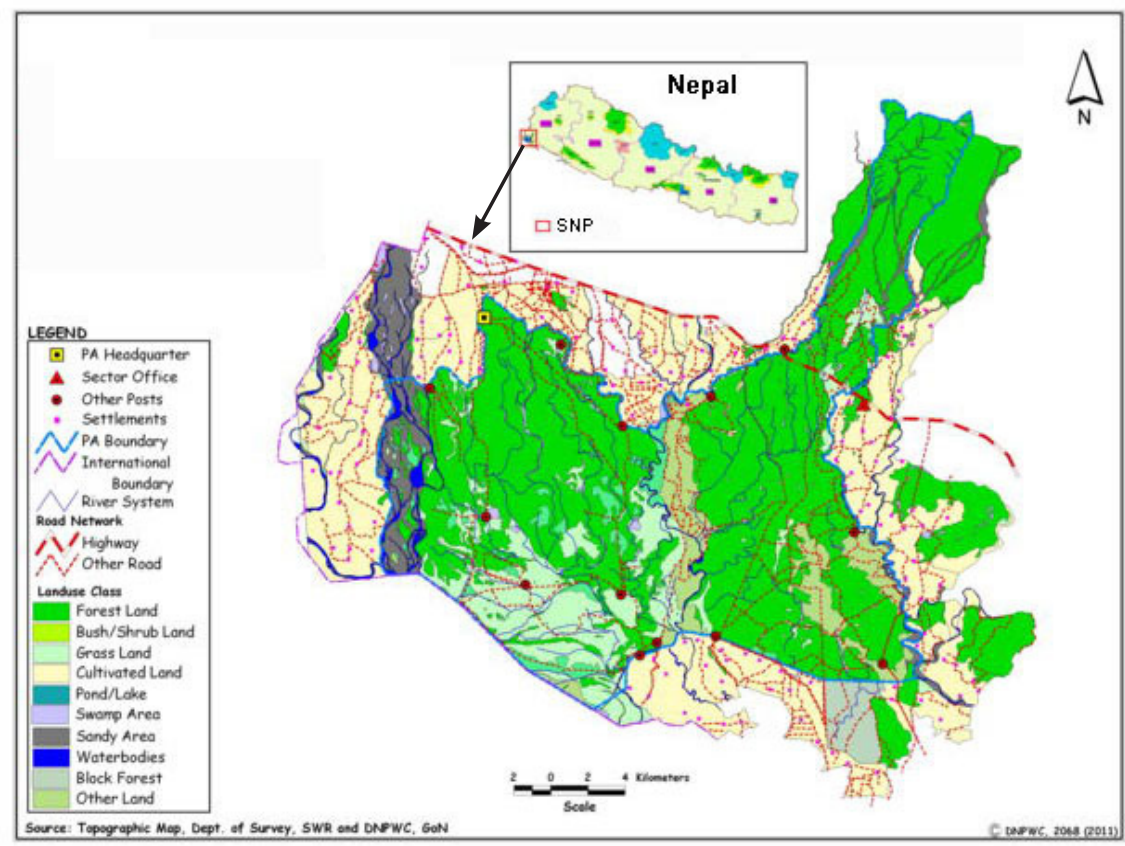


The climate of the region is subtropical monsoonal with mean annual rainfall of $1,579 \mathrm{~mm}$ (62.2 in) that occurs mainly from June to September and is highest in August. The winter months of December and January are fairly cold with day time temperatures of $7-12{ }^{\circ} \mathrm{C}\left(45-54^{\circ} \mathrm{F}\right)$ and occasional frost. February onwards temperature rises up to $25^{\circ} \mathrm{C}\left(77^{\circ} \mathrm{F}\right)$ in March and reach $42^{\circ} \mathrm{C}\left(108^{\circ} \mathrm{F}\right)$ by the end of April (DNPWC, 2013).

This National park is the rich Tarai protected area in terms of floral diversity which protects more than 665 species of plants belonging to 438 genera within 118 families and it is the highest, reported for any given protected areas in Tarai (Aryal and Yadav, 2010). Sal (Shorearo busta) is the predominant species in the National park. Shuklaphanta is equally rich in faunal diversity and supports more than 53 species of mammals among which swamp deer (Cervus duvaucelii) is the most popular species due its large herd size and number (Chalise, 2008). SNP is also a home to Golden monitor lizard (Varanus flavescens), Bluebull (Bosel aphustragocamellus), Barking deer (Muntiacus muntjak), Hog deer (Axis porcinus), Wild boar (Sus scrofa), Leopard (Panthera pardus), Jackals (Canis aureus), Langur (Semnopithecus entellus), Rhesus monkey (Macaca mulatta) and different species of small mammals (Chalise, 2012, Gyawali, 2003).

\section{Data collection}

The study was conducted in two seasons in between November 2015 to May 2016: winter/before burning (November-December, 2015) and summer/after burning (April- May, 2016). Direct count of hare is not a suitable method to determine its distribution on a fine-grained scale (Burnham, Auderson \& Laake, 1980, Buckland, Anderson \& Burnham, 1993). Pellet gives higher diversity value than the direct observation (Redpath, Clarke, Madder \& Simon, 2001). Many factors restricted the selection of transect and indirect count method; consequently, not all the grasslands could be surveyed during the study. This is because some of the grassland patches were too large to reach up to the center, isolated, quite far from the road network of the Park and walking on foot through these tall grasslands involved significant risk from animal attack because of presence of potentially dangerous mammals like tiger, rhino, elephant and wild boar. Taking into consideration the size of the Hispid hare and its habitat of tall grassland makes it impossible to even see them; therefore, pellet count method was followed to determine the population density. 


\section{Field survey}

Four study sites (Pipariya study area -1, Barcaula study area-2, Shuklaphanta study area-3, Hirapurphanta study area-4) were selected for Hispid hare study. Four types of habitats (tall grassland, short grassland, open grassland and forest) were selected for surveying the presence or absence of Hispid hare pellets. Strip transects each of $20 \mathrm{~m}$ length and $2 \mathrm{~m}$ width were randomly laid in the Hispid hare's potential distribution area. A total of 185 strip transects were observed before the annual fire burning and 210 were sampled after the fire and each transect was covered by two people carefully looking pellet groups of the animal. Pellet density, in turn Population density was calculated on the basis of second time count method after 10 days interval using only the fresh pellet data. All pellet groups including fresh and old that were found in the first-time survey were counted and cleared from the plot for the second-time count. To calculate pellet density and population density, we followed defecation rate- 9 as explained by Aryal, Brunton, Yadav, Adhikary, \& Raubenheimer (2012) and Nath and Machary (2010). During data collection, the parameters noted were number of pellet groups, nature of pellet (old/fresh), distance of the pellet groups from the nearest water source and the vegetation type. Whenever the Hispid hare pellets were encountered, the GPS points were noted, number of pellets were counted and the vegetation sampling was done. Indirect evidences like pellets, dungs and scats of other wild animals were identified with the help of the senior knowledgeable forest staff.

\section{Data analysis}

Pellet density and population density was estimated by following formula (Yadav, 2005).

Pellet Density $\left(\frac{\mathrm{N}}{\mathrm{ha}}\right)=\frac{\text { Total Pellet Groups }}{\text { Transect Area } \times \text { Transect Number }} \times 1000$

Population Density $\left(\right.$ per ha) $=\frac{\text { Observed Pellet Density in Specific Time Period }}{\text { Estimated Defecation Rate for Same Time Period for Single Animal }} \times 1000$

The significance in the difference of population density in study sites between winter and summer was tested by Two-sample T-test.

Habitat preference (HP) was calculated by using the formula:

$\mathrm{HP}=\frac{\mathrm{PPE}}{\mathrm{TPP}} \times 100$ 
Where, $\quad \mathrm{HP}=$ Habitat preference,

$\mathrm{PPE}=$ Pellet present $(\%)$ in each habitat

$\mathrm{TPP}=$ Total pellet present $(\%)$ of the all habitat types

The statistical significance of the difference in population density among the study sites, difference in occurrence of pellets percentage among different distance from nearest water source and difference in habitat preference were tested by $\chi^{2}$ - test.

\section{Vegetation Analysis}

For vegetation analysis of the Hispid hare habitat, layout of transects and plots were same except for the plot shape and size. The quadrates of $10 \mathrm{~m} \times$ $10 \mathrm{~m}, 4 \mathrm{~m} \times 4 \mathrm{~m}$ and $1 \mathrm{~m} \times 1 \mathrm{~m}$ were used for tree layers, woody undergrowth and grass species, respectively. For the vegetation analysis in a quadrate we counted the number of grass blades in a particular grass clump instead of counting the whole grass clump as one individual as suggested by Nath, \& Machary, (2010). The frequency, relative frequency, and relative density were calculated by using following formulas (Odum, 1971):

Frequency of 'A' Species $=\frac{\text { Number of Quadrates in which Species A occur }}{\text { Total Number of Quadrates }} \times 100$ Relative Frequency $(\mathrm{RF})=\frac{\text { Frequency of Species A }}{\text { Sum of Frequency of all Species }} \times 100$

Density of Species 'A' $=\frac{\text { Frequency of Species A in All Quadrates }}{\text { Total Number of Quadrates Size of Quadrates }}$ Relative Density of Species 'A' (RD) $=\frac{\text { Number of Individuals of Species A }}{\text { Total Number of Individuals of All Species }} \times 100$

\section{RESULT AND DISCUSSION}

\section{Pellet density and population density}

The Hispid hare pellets were observed in 50.81 percentage transects (94 out of 185) in winter and 77.6 percentage (163 out of 210) in summer. The population density of Hispid hare was calculated by dividing the pellet density by the estimated defecation rate (Table 1). The average Population density of Hispid Hare in different study areas of Shuklaphanta National Park before the fire (in winter) and after fire (in summer) was $0.1820 /$ ha and $0.2268 /$ ha respectively. The highest population density was found at 
Hirapurphanta $(0.2252 / \mathrm{ha})$ in winter and at Shuklaphanta $(0.3186 / \mathrm{ha})$ in summer. The population density was higher in summer season than in winter in all four study sites, but there was no significant difference in their mean [two-sample $\mathrm{t}(\mathrm{df}=3)=1.486, \mathrm{p}=0.187$ ]. In the same way, there was no significant difference of the population density of Hispid hare in four study sites for both the seasons (winter: $\chi^{2}=2.18$, $\mathrm{df}=3, \mathrm{P}=0.535$; summer: $\left.\chi^{2}=6.81, \mathrm{df}=3, \mathrm{P}=0.078\right)$.

Table 1: Population density of Hispid hare in different study sites within Shuklaphanta National Park during 2015-2016.

\begin{tabular}{|l|l|l|l|l|l|l|}
\hline \multirow{2}{*}{ Study Sites } & \multicolumn{2}{|l|}{$\begin{array}{l}\text { Population } \\
\text { Density (/ha) }\end{array}$} & \multicolumn{2}{l|}{$\begin{array}{l}\text { Surveyed } \\
\text { Area }\left(\mathbf{m}^{2}\right)\end{array}$} & \multicolumn{2}{l|}{$\begin{array}{l}\text { Average } \\
\text { Density/ha }\end{array}$} \\
\cline { 2 - 5 } & Winter & Summer & Winter & Summer & Winter & Summer \\
\hline Pipariya & 0.1461 & 0.2032 & 1720 & 1800 & & \\
\hline Barcaula & 0.1586 & 0.1602 & 1600 & 2240 & \multirow{2}{*}{0.1820} & \multirow{2}{*}{0.2268} \\
\hline Shuklaphanta & 0.1983 & 0.3186 & 2400 & 2680 & & \\
\hline Hirapurphnata & 0.2252 & 0.2923 & 1680 & 1680 & & \\
\hline
\end{tabular}

\section{Grass Community and pellet distribution}

Altogether, 12 grass species were found in Hispid hare habitat in Pipariya, Barcaula, Shuklaphanta and Hirapurphanta area. In Pipariya site Narenga porphyrocoma (RF-23.45\%) was the most common grass species in Hispid hare habitat followed by Imperata cylindrica (RF-22.75\%) in winter, and Imperata cylindrica (RF-23.89\%) followed by Saccharums pontaneum (RF-23.21\%) in summer. Whereas, in the Barcaula site, most commom species was Naranga prophyrocoma in both winter and summer season (RF-31.17\% in winter and RF-25.50\% in summer) followed by Imperata cylindrica (RF-14.03\% in winter and RF-17\% in summer) and Saccharum spontaneum (RF-11.22\% in winter and RF- $14.27 \%$ in summer). In Shuklaphanta site, most common species was Imperata cylindrica in both seasons (RF-22.72\% in winter and RF-24.09\% in summer) followed by Saccharum spontaneum (RF-22.27\% in winter RF- $22.65 \%$ in summer) and Saccharummunj (RF-13.86\% in winter and RF-13.86\% in summer). Similarly, in Hirapurphanta, most abundant species was Imperata (RF$41.01 \%$ in winter and RF-34\% in summer) followed by Saccharum spontaneum (RF-24.19\% in winter and RF-15.41\% in summer) and Cynodon dactylon (RF-13.98\% in winter and RF-27.21\% in summer). 
Fig. 2: Percentage of observed pellets in different vegetation types

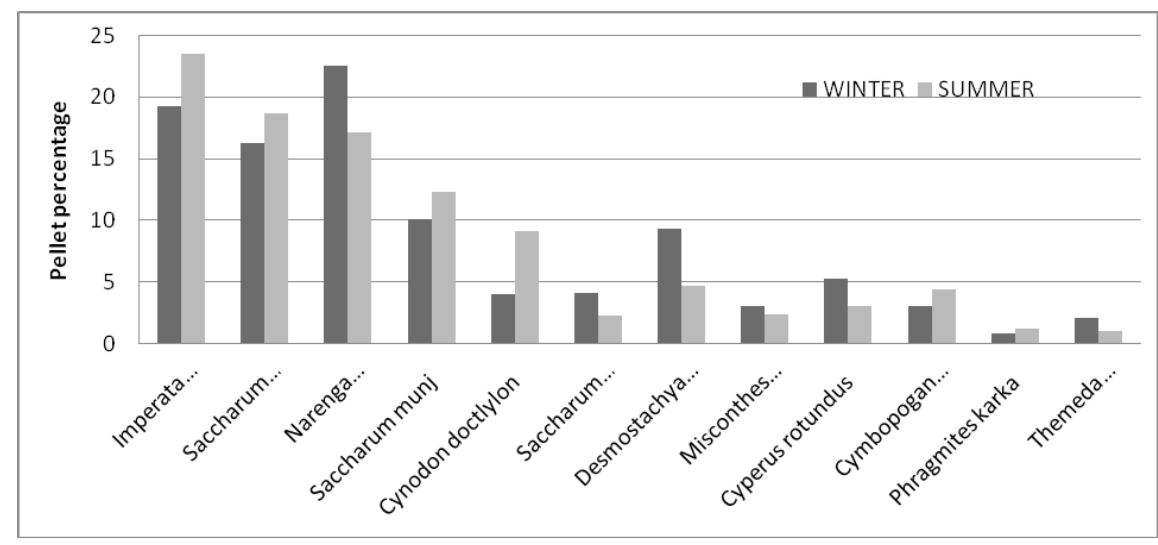

Highest percentage of Hispid hare pellets were observed in Narenga porphyrocoma $(22.56 \%)$ dominated habitat in winter season and in Imperata cylindrica $(21.48 \%)$ dominated habitat during summer season (Fig. 2). During the field visit, most of the soft part of stem of Narenga porphyrocoma, leaves of Cynodon ctylon, Imperata cylindrica and inner core of the Saccharum spontaneum were seen eaten as food by Hispid hare.

\section{Water availability and pellet distribution}

The distribution of Hispid hare pellets from the nearest water source ranged between the mean distance of $150 \mathrm{~m}$ to $700 \mathrm{~m}$ in winter and $315 \mathrm{~m}$ to $950 \mathrm{~m}$ in summer. In Pipariya, there was the least distance between the observed pellets and water body (mean distance $150 \mathrm{~m}$ and $315 \mathrm{~m}$ in winter and summer respectively) while in Hirapurphanta that was the highest (mean distance $700 \mathrm{~m}$ to $950 \mathrm{~m}$ in winter and summer, respectively) (Fig. 3). Significantly highest minimum distance between the occurrence of pellets and the water body for both the seasons was in Hirapurphanta, followed by the Shuklaphanta (winter: $\chi^{2}=547.56, \mathrm{P}<0.001$; summer: $\chi^{2}=343.498$, $\mathrm{P}$ $<0.001)$. 
Fig. 3: Mean nearest water distance in different study sites, in SWR.

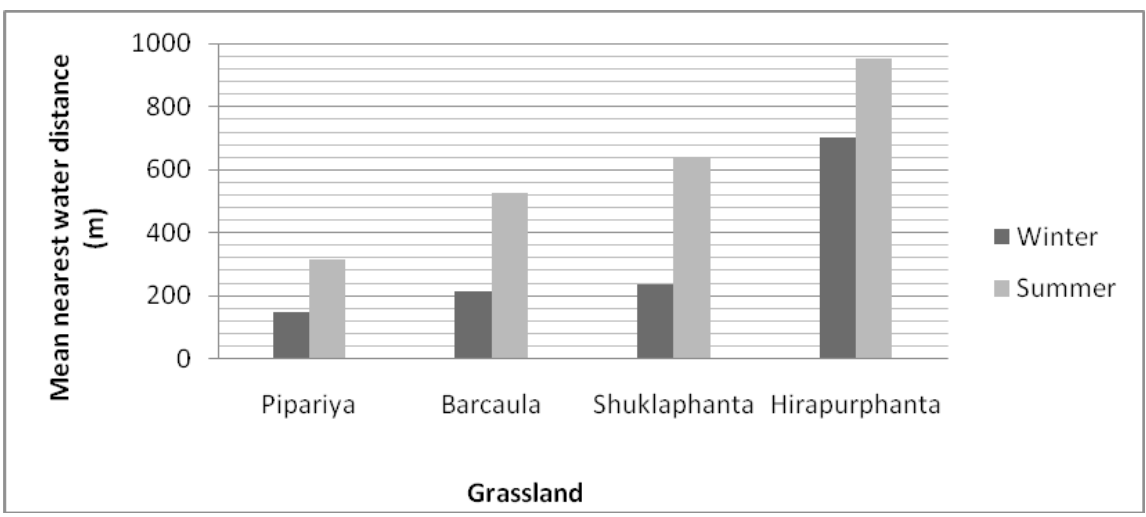

No evidence of Hispid hare pellets was seen very near to the water sources. After fire, number of observed pellets were higher in places distant from the water sources $(300 \mathrm{~m}$ to $950 \mathrm{~m})$ compared to before the fire $(150$ $\mathrm{m}$ to $650 \mathrm{~m}$ ). The sets of pellet occurrence data were classified into six categories on the basis of nearest distance between the water source and the observation of pellets, viz: A (0-200 m), B (201-300 m), C (301-400 m), D (401-500 m), E (501-600 m), F (>600 m). The highest percentage of the pellets were observed from the water distance of class $\mathrm{C}(25.23 \%)$ in winter and Class D (35.67\%) in summer (Fig. 4).

Fig. 4: The percentage distribution of Hispid hare pellets according to the nearest water distance.

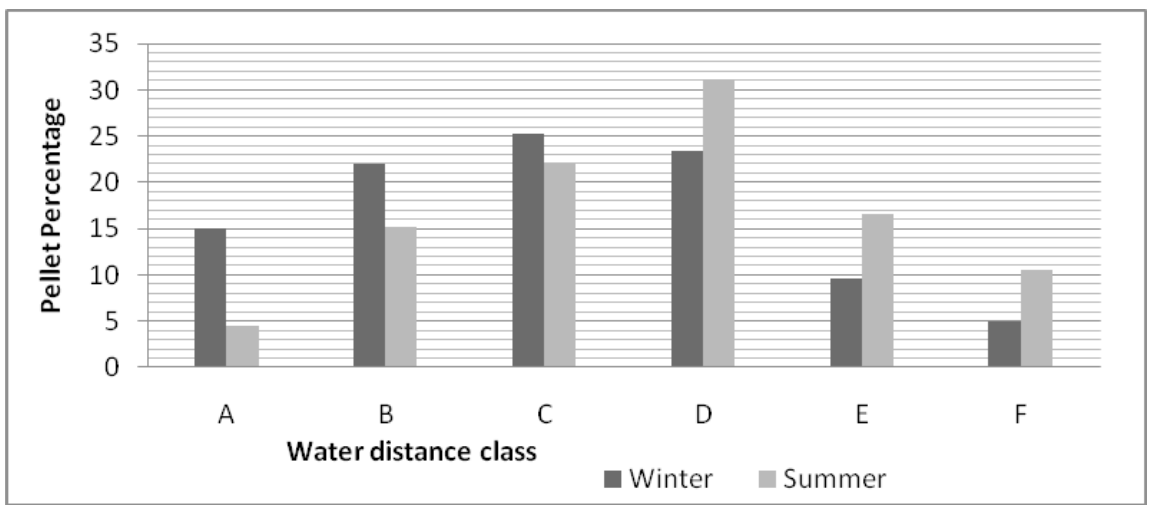


10 DISTRIBUTION AND HABITAT PREFERENCE OF ...

\section{Ground cover and pellet distribution}

Among the four study sites, Shuklaphanta had the highest coverage percentage (90\%) in winter (before the fire) and (66\%) in summer, whereas Hirapurphanta had the least coverage $(55.50 \%)$ in winter and $(35.65 \%)$ in summer season (Fig. 5). Regarding the ground coverage percentage, the habitatsof Hispid hare pellet observation hare were classified into 4 classes, Viz: A (0-20\%); B (21-40\%); C (41-60\%); D (>60\%).

Fig. 5: Mean coverage percentage of plant species in study areas.

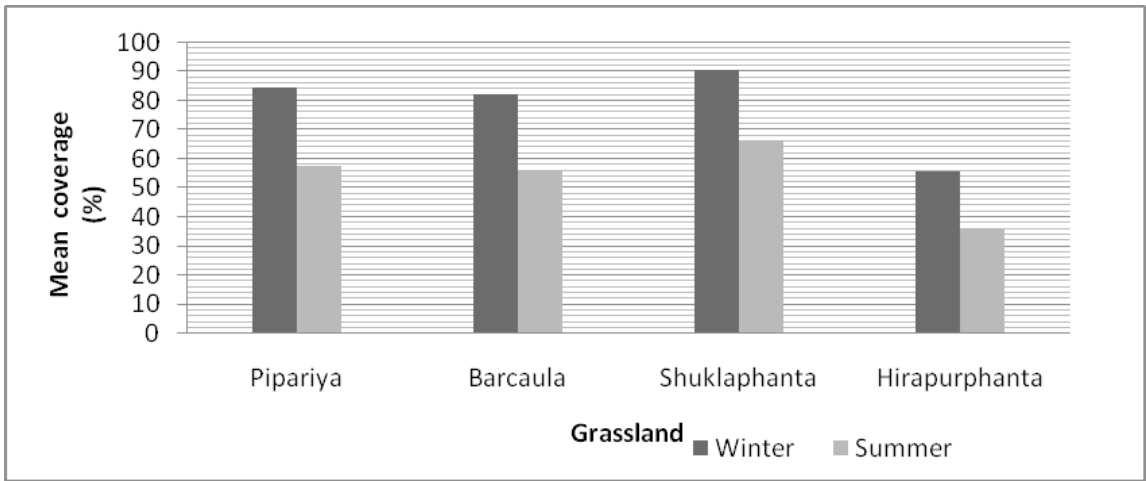

Hispid hare was found to prefer the area with higher ground coverage, because most of pellets ( $76 \%$ in winter and $47 \%$ in summer) were observed in the area with coverage more than $>60 \%$ (Fig. 6).

Fig. 6: Mean coverage percent of plant species in study sites, in SWR.

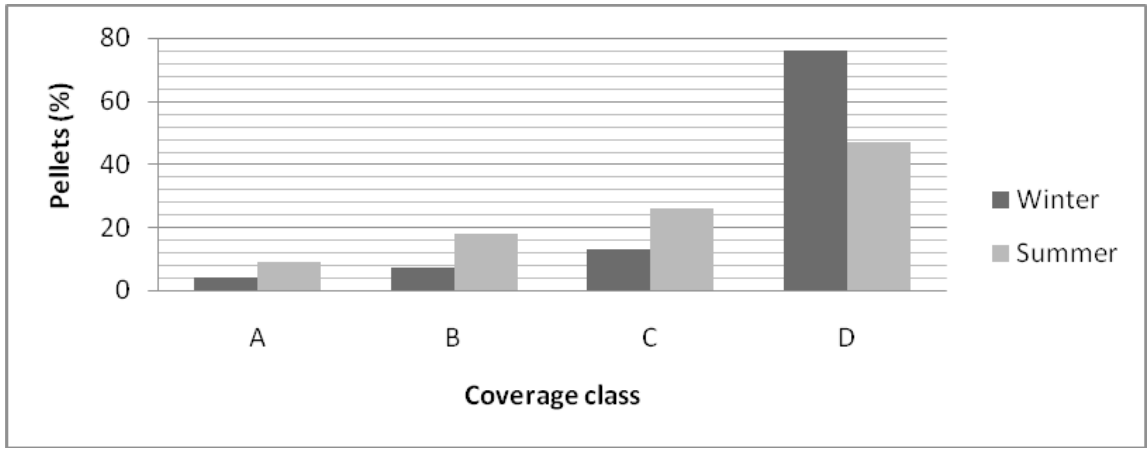

\section{Habitat type and preference}

The Habitat found to be utilized by Hispid hare was classified into 4 categories. 
- Tall Grassland (Containing grasses of $>2 \mathrm{~m}$ height)

- Short Grassland (Grass height from $25 \mathrm{~cm}$ to $2 \mathrm{~m}$ )

- Open Grassland (Grasses of $<25 \mathrm{~cm}$ height)

- Forest (Dominated by trees of any species)

Total number of plots in each habitat type in both winter and summer seasons with and without pellets and habitat preference was dealt (Table 2).

Table 2: Habitat preference (HP) value during wenter and summer.

\begin{tabular}{|l|c|c|c|c|c|c|}
\hline \multirow{2}{*}{ Habit types } & \multicolumn{2}{|c|}{ Total No. of plots } & \multicolumn{2}{c|}{ Plots with pellets } & \multicolumn{2}{c|}{ HP (\%) } \\
\cline { 2 - 7 } & Winter & Summer & Winter & Summer & Winter & Summer \\
\hline Tall Grassland & 108 & 95 & 83 & 89 & 70.51 & 42.74 \\
\hline Short Grassland & 36 & 73 & 9 & 61 & 22.93 & 38.12 \\
\hline Open Grassland & 28 & 31 & 2 & 13 & 6.55 & 19.13 \\
\hline Forest & 13 & 11 & 0 & 0 & 0 & 0 \\
\hline Total & 185 & 210 & 94 & 163 & & \\
\hline
\end{tabular}

Among 4 different habitat types, tall grassland (both in winter and summer) was the most preferred (HP value 70.51\% in winter and $42.74 \%$ in summer) followed by short grassland (HP value $22.93 \%$ in winter and $38.12 \%$ in summer) and open grassland (HP value $6.55 \%$ in winter and $19.13 \%$ in summer). But we failed to collect the pellets from forest during the study period in both winter and summer season. The pellet distribution pattern in different habitat types of SNP depicted statistically significant higher preference of Hispid hare to tall grassland for both the seasons (winter: $\chi^{2}=121.61, \mathrm{df}=2, \mathrm{p}<0.001$, summer: $\left.\chi^{2}=45.86, \mathrm{df}=2, \mathrm{P}<0.001\right)$.

\section{DISCUSSION}

Hispid hare is one of the least studied endangered small mammal species of the world. Historically the species was distributed throughout the southern lowland of Nepal to Uttar Pradesh, West Bengal to Assam of India. We do not have good evidence of its distribution in different protected areas of Nepal except Shuklaphanta National park and Bardiya National Park (Chalise 2008). Due to less in number and isolated population it is less explored. Nepal considered it protected by law but its survival and conservation threats are never evaluated. The park people interaction during Kharkhadai and confusion with common hare species has caused the 


\section{DISTRIBUTION AND HABITAT PREFERENCE OF ...}

declination of its number and survival. Direct count of hare is not a suitable method to determine its distribution on a fine-grained scale (Burnham, Anderson, \& Laake, 1980 and Buckland, Anderson \& Burnham 1993). Hispid hare is nocturnal animal (Aryal and Yadav, 2010). So, the population estimation and direct census is very difficult. Therefore, in the present study, pellet count in strip transect and vegetation survey was applied to explore Hispid hare distribution and habitat use. The present study was conducted in Shuklaphanta National park of Kanchanpur district, located in the Farwestern Terai, on the southwestern edge of Nepal. The study was done in both winter season and summer season. A total of 185 plot in winter and 210 in summer were used in four study sites to count the (fresh and old) pellet groups and vegetation analysis.

The present population density of Hispid hare before and after fire was $0.1820 /$ ha and $0.2208 /$ ha respectively whereas as Bell (1987) reported a population density of 6.10 /ha and Yadav (2005) reported it to be $1.01 /$ ha in this region. This indicates the population density is decreasing. The reason behind decline in hare population is unscientific burning of grass, invasion of grassland by broadleaved trees, over grazing, and flooding and thatch collection. Previous studies of Yadav (2005), and Aryal, Brunton, Ji, Yadav, Adhikary \& Raubenheimer (2012) explained these existing threats as the major causes of population decline in SNP. and on (2009) reported a population density of 0.45 individuals/ha in Bardiya National Park before burning and $0.967 /$ ha after burning. In our study also, the population density was higher in the observations after burning (0.2208) than in the observations before burning (0.1820); but the calculated population density in SNP was quite lower than in Bardiya National Park. Aryal et al. (2012) reported 0.06 individuals/ha, with a maximum total SNP population of 219 \pm 40 . Maheswaran and Smith (2000) in Jaldapara Wildlife Sanctury reported population density $0.087 /$ ha. Recently, Nath and Machary (2015) reported population density of 3.81/ha in Manas National Park India. Comparing these studies, it appears that SNP has the less current Hispid hare population density. The reason behind declining the population is unscientific grass burning and cutting of SNP in December and January that coincides with the breeding season of Hispid hare.

Yadav (2005) explained that the main food species consumed by Hispid hare is Narenga porphyrocoma and ground cover is dense in dry places rather than wetland. He reported most of the pellets found in the average distance of $600 \mathrm{~m}$ from water and no pellets were closer than $290 \mathrm{~m}$ 
to water. Maheswaran (2002) reported the preference of tall grassland than the short grassland in Dudwa National park, India. The current study also showed the preference of tall grassland by Hispid hare and the nearest distance for water and pellets ranged from $150 \mathrm{~m}$ to $650 \mathrm{~m}$ in winter and $300 \mathrm{~m}$ to $950 \mathrm{~m}$ mean distance. Nath et al. (2010) observed nine species of grasses in Hispid hare habitat among which the most dominant and frequent species was the Imperata cylindrica and most of the pellets occurred in such habitat. We observed the highest percentage of Hispid hare pellets in Narenga porphyrocoma $(22.56 \%)$ dominated habitat in winter season and in Imperata cylindrica (21.48\%) dominated habitat during summer season. Contrastingly, in Bardia National Park Hispid hare mostly preferred open area rather than tall grassland habitat; showing higher preference to riverine and open area in winter and tall grass in summer season (Tandon, 2009). In this study, Hispid hare mostly preferred tall grassland (HP value 70.51\% in winter and $42.74 \%$ in summer), short grassland $(22.93 \%$ in winter and $38.12 \%$ in summer), and open grassland (HP value $6.55 \%$ in winter and $19.13 \%$ in summer) in both summer and winter seasons. These observations were similar to that of Nath \& Machary (2010) and Aryal, Brunton, Ji, Yadav, Adhikari, \& Raubenheimer (2012).

In our observations, we failed to collect fresh pellets in transect one week after burning, which is perhaps due to lack of cover and food. Maheswaran (2002) also found that Hispid hare use recently burnt grassland patches less than tall grassland areas; but no evidence of Hispid hare feeding was recorded during the field survey. Occurrence of pellet groups was more in areas where ground was dense, away from water resources, similar to the observations in previous studies (Aryal, Brunton, Ji, Yadav, Adhikary \& Raubenheimer, 2012, Nath and Machary 2010, Yadav, 2005).

Pellet groups deposition rate is generally increased when the density of ground cover increases from the moderate to dense. In addition to the feeding grounds, hares need cover against predators and places for breeding to successfully thrive (Maheswaran, 2002). Hispid hare has the habit of cutting the grass $15 \mathrm{~cm}$ above the ground level to feed on the inner sap of the grass stem (Maheswaran \& Kumar, 2008). In SNP, Hispid hare signs were more frequently found in areas distant from water when new grown grass existed after burning compared to when only unburned grass was present. This suggest that Hispid hare benefits from the water content of new growth grasses enabling them to expand their range away from water sources after fire (Aryal, Brunton, Ji, Yadav, Adhikary \& Raubenheimer 2012). This 


\section{DISTRIBUTION AND HABITAT PREFERENCE OF ...}

confirms the Hispid hare select habitat that provides both shelter and food. From this study, the selected site Shuklaphanta has higher coverage percent and Hirapurphanta has less coverage during the winter season. Not all grasslands could be surveyed, by potentially dangerous animals including Asian Elephant, Greater One-horned Rhinoceros (Rhinoceros unicornis), Tiger (Panthera tigris). Nevertheless, the information generated during this preliminary ecological study provides baseline information, which will help in planning future studies and in guiding efforts by the park authority to set up of effective conservation measures for this very rare and endangered species.

\section{CONCLUSION}

The average population density of Hispid hare in SNP was found to be $0.1820 /$ ha in winter and 0.2208 /ha in summer, which is a very low when compared with the past works in SNP and elsewhere. It preferred the grass species like Imperata cylindrica, Narenga porphyrocoma and Saccharum spontaneus its food. Among four different habitat types Hispid hare showed highest preference to the tall grassland before fire and after fire; followed by short grassland and open land, while pellets were apparently absent from forest habitat. The pellet density increased far from the water sources after fire compared to before the fire and the species preferred areas with higher ground cover by the grasses. Considering very low population density of Hispid hare in SNP, we recommend for the efficient conservation efforts with scientific burning practice grassland management, prevention of over grazing and flooding, and regular monitoring of the population.

\section{WORKS CITED}

Adhikari, T.R. (2001). Small Mammal's Biodiversity and Grassland Management in the Western Tarai of Nepal. A study report submitted to the University of East Anglia, UK.

Adhikari, P. (2003). Status, Dispersal and Habitat use of greater one horned rhinoceros (Rhinoceros unicornis) in RSWR far western lowland Nepal. M.Sc. dissertation submitted to the Central Department of Zoology, TU.

Aryal, A. and Yadav, H.K. (2010). First camera trap sighting of critically endangered hispid hare (Caprolagus hispidus) in Shuklaphanta wildlife reserve: Nepal. World Applied Science Journal, (9). pp. 367-371. 
Aryal, A., Brunton, D., W. Ji, Yadav, H.K., Adhikari, B and Raubenheimer, D. (2012). Diet and habitat use of Hispid Hare caprolagus hispidus in Shuklaphanta wildlife reserve, Nepal. Mammal Study, 37(2). pp. $147-154$.

Bell, D.J. (1986). A study of the Hispid Hare Caprolagus hispidus in royal Shuklaphanta wildlife reserve, western Nepal: 'A After Burning Report', (23). pp. 24-31.

- - - (1987). Study of the biology and conservation problems of the Hispid Hare report submitted to University of East Anglia, England. pp. 38.

Buckland, S.T., Anderson, D. R., and Burnham, K.P. (1993). Distance sampling. London: Chapman and Hall.

Burnham K.P., Anderson D.R., and Laake J.L.(1980). Estimation of density from line transect sampling of biological populations. Wildlife Monograph (72). pp. 1-202.

Chalise, M.K. (2008). Nepalka samrakshit banyajantu (in Nepali), Kathmandu: Shajha Prakashan. pp. 116+12.

- - - (2012). Nepalka aanautha tatha durlav banyajantuharu (in Nepali). Kathmandu: Bibek Srijanshil Publication, p. 76.

- - - (2014). Nepalka Kharayo Prajatiharu. Revoscience, Vol. IV, no. IV, July. pp. 21-22.

Chapman, J.A. and Flux, J.E.C. (1990). Rabbits, Hares and Pikas: Status survey and conservation action plan. IUCN/SSC Lagomorph Specialist Group, Gland, Switzerland. pp. 177.

DNPWC. (2013). Annual report, Department of National Park and Wildlife Conservation Kathmandu.

Gyawali, N. (2003). Status and Habitat Use of Barasingha (Cervus duvauceli) Population in Royal Shuklaphanta Wildlife Reserve, Far Western Lowland, Nepal. B.Sc. Forestry thesis. submitted to IOF, TU.

Inskipp, C. and Collar, N.J. (1984). The Bengal florican-its conservation in Nepal. Oryx 18 (1). pp. 30-35.

Maheswaran, G. (2002). Status and ecology of endangered hispid hare Caprolagus hispidus in Jaldapara wildlife sanctuary. west Bengal, India. Bombay. Newyork: Natural History Society and Wildlife Conservation Society, p. 47. 


\section{DISTRIBUTION AND HABITAT PREFERENCE OF ...}

Maheswaran, G. and Kumar, A. (2008). Trapping success and inventory of small mammals in Jaldapara wildlife sanctuary, India, Tiger Paper, 35(1). pp. 22-28.

Nath, N.K. (2009). Status survey of Hispid Hare Caprolagus hispidus in the North Bank Landscape (Assam and Arunachal Pradesh), India. A Technical Report, Aaranyak, p.58.

Nath, N.K. Sarkar, \& Machary, K. (2010). Ecological assessment of Hispid hare in Manas National Park, India. A Technical Report. Aaranyak, Guwahati, p. 44.

Odum, E.P. 1971. Fundamentals of Ecology ( ${ }^{\text {rd }}$ Ed). Saunders College Publishing, Philadelphia, p. 574.

Oliver, W.L.R. (1979). The doubtful future of the Pygmy Hog and the Hispid Hare. Pygmy Hog survey report - Part 1. Journal of Bombay Natural History Society, 75(2) pp. 337-341.

- - - (1980). The Pygmy Hog: the biology and conservation of the Pygmy Hog, Sussalvanius and the Hispid Hare, Caprolagus hispidus. Special Scientific Report No. 1. Jersey Wildlife Preservation Trust, Jersey, UK, p. 120.

- - - (1985). The distribution and status of Hispid hare Caprolagus hispidus and some additional notes on pigmy hog Suss alvanius. A report on the 1984 field survey in northern Bangladesh.

Redpath, D.L., Clarke, R., Madder, R. and Simon, J.T. (2001). Assessing raptor diet: comparing pellets, prey remain, and observational data at Hen Harrier nests.

Shrestha, T.K. (1997). Mammals of Nepal: with reference to those of India, Bangladesh and, Pakistan. Kathmandu: Printers Teku.

Tandon, P. (2009). Population status, habitat utilization, distribution and conservation threats of hispid hare in Bardiya National park of west Nepal. Current Science 105(5), pp. 691-694.

Wilson, A. (1924). Sport and service in Assam and elsewhere. London: Hutchinson \& Co.

Yadav, B. (2005). Status, Distribution and Habitat use of Hispid Hare (Caprolagus hispid) in Royal Shuklaphanta Wildlife Reserve, B.Sc. thesis submitted to IOF, TU. p. 53. 